\title{
Review Essay Karl Schlögel: Toward a Holistic View of Ukraine
}

\author{
Serhiy Bilenky \\ Canadian Institute of Ukrainian Studies, Toronto Office, University of Alberta
}

Karl Schlögel. Ukraine: A Nation on the Borderland. Translated by Gerrit Jackson, Reaktion Books, 2018. 288 pp. Illustrations. Further Reading. $£ 25.00$, cloth.

\section{IMAGINING UKRAINE}

The Ukraine will one day become a new Greece; the beautiful climate of this country, the gay disposition of the people, their musical inclination, and the fertile soil will all awaken. From so many small tribes which in the past were Greeks there will rise a great and cultured nation and its boundaries will extend to the Black Sea, and thence into the far-flung world. (Pritsak 254)

$\mathbf{T}$ This is the translated, widely quoted observation of the German preRomantic philosopher Johann Gottfried Herder (1744-1803) from his travel diary, published in 1769. Most likely, he had never actually travelled to Ukraine-only in his fervid imagination. But from the time that Herder's words gained renown, large numbers of Western European and Russian leisure travellers went to Ukraine in search of exotic pleasures, picturesque scenery, and historical authenticity. What they found, though, was not Greece, but a different type of southern country, and Ukraine came to be viewed through the prism of this notion for most of the nineteenth century. The monikers "Russia's Italy" and "(trans-)Dnieper Italians" were widely attributed to Ukraine and its population. These were flattering names, but they had a darker side. Until the end of the nineteenth century, Italy was seen as a "female" in need of the sort of protection that could only be assured by "men" from the North-generally Britain, Germany, and the United States. In Eastern Europe, the image of the masculine North was embodied by Great Russia, while the feminine South was associated with Ukraine. Russians travelling to Ukraine discovered their own Italy. In this idealized southern world, which was imagined as something akin to a rustic family ruled by love and faith, where wives loved and served their husbands, the northerners were the symbolic husbands and lovers. In addition, the "natural" mores of the southerners stood in contrast to the more "enlightened" ways of the 
North. As history has shown, the leisure travellers followed or were followed by armed invaders, economic opportunists, and technical experts, whose goals were to discipline the natives, colonize their country, and open up its reaches for the metropolitan centre to consume. The references to Italy gradually dissipated, but most travellers to Ukraine continued to espouse an unmistakably condescending, if not outright colonial, view.

The twentieth century witnessed the rise of more-personal journeys-of self-discovery and in search of one's roots. This type of journey has been most famously fictionalized in Jonathan Safran Foer's breakthrough novel Everything is Illuminated (2002). The book's protagonist (and perhaps the author as well), in discovering the mysteries of post-Soviet Ukraine, is (re)discovering himself. This narrative device is typical of the travel narratives of westerners with some roots in Eastern Europe. In fact, the Jewish American hero (incidentally also called Jonathan Safran Foer) returns to a place where he always somehow belonged. "After three years he returned to the shtetl," writes Foer about his protagonist Yankel-Safran, and then he adds about himself, "I am the final piece of proof that all citizens who leave eventually return" (Foer 47). The Ukraine of the novel displays all of the usual stereotypes pertaining to the post-Communist "Wild East" (such as shabby cafes and hotels, people's fears about being robbed or having their things stolen while on a train or on the mean streets, and so on). More importantly, the description of the fictitious shtetl called "Trachimbrod" is deliberately ahistorical and mythological (the narratives about Jewish life there do not mention any historical events; nor do they even refer to the shtetl's location-it could be imperial Russia, Habsburg Galicia, interwar Poland, or Soviet Ukraine). This is reminiscent of the literary genre of magical realism, which is typified by the writings of Jorge Luis Borges and Gabriel García Márquez. Also, myth permeates concrete historical events with universality. In the book, myth and fantasy help the protagonists and the reader better understand, or "illuminate," the traumatic events at the centre of the literary travelogue-the Holocaust in fictitious Trachimbrod and the memory, or rather silence, about it in contemporary Ukraine.

Trauma, however, is different for every traveller. And in contrast to novelists like Foer, non-fiction writers are less prone to indulge in myth or fantasy as a means of "illuminating" traumatic events. For instance, for Michael Ignatieff, a noted Canadian political thinker who also traces his roots back to Ukraine, a family trauma stems not from the Holocaust but from the Bolshevik Revolution of 1917. In his well-known and widely discussed book Blood and Belonging: Journeys into the New Nationalism, Ignatieff devotes a number of controversial pages to his trip to Ukraine just after it had regained its independence in 1991. He acknowledges his Russocentric perspective. This fact caused him some trouble with Toronto's Ukrainian community after 
his book was published and he became involved in Canadian politics: "My difficulty in taking Ukraine seriously goes deeper than just my cosmopolitan suspicion of nationalists everywhere. Somewhere inside, I'm also what Ukrainians would call a Great Russian, and there is just a trace of old Russian disdain for these 'little Russians'" (Ignatieff 108). Besides the unpleasant surprises of post-Soviet life, Ignatieff's other concern was coming to terms with the fact that his family nest, just like the city of Kyiv nearby, was now located in independent Ukraine rather than in Russia. His "return" to the land of his ancestors is expressed in the virtual "recognition" of his Russian grandfather's home in a Ukrainian village: "I begin to have an eerie sense of familiarity," he says, although he had never been there before (Ignatieff 118). He then boasts about surreal encounters with local peasants who kissed his hands as if an old master had finally returned to his possessions. In Ignatieff's case, the graves of his Russian aristocratic ancestors create his "eerie" link to Ukraine. The philosophical traveller writes,

Nations and graves. Graves and nations. Land is sacred because it is where your ancestors lie. Ancestors must be remembered because human life is a small and trivial thing without the anchoring of the past. Land is worth dying for, because strangers will profane the graves. (Ignatieff 124-25)

What Ignatieff has difficulty admitting is that the native country of his dead and dispersed ancestors is indeed populated by "strangers." And a barely veiled colonial perspective seems to be his instinctive reaction to the trauma resulting from his existential estrangement from contemporary Ukraine. Is it at all possible to travel without reliving one's own personal or family traumas and without backsliding into having an undeniably colonial view? A few sympathetic foreigners who have made their way across postEuromaidan Ukraine have recently demonstrated that a new kind of travel and travel-writing is certainly possible. The best examples of this new type of "travelogue" include Tatuaż z tryzubem (Tryzub Tattoo, 2015), by Polish journalist Ziemowit Szczerek; Black Square: Adventures in Post-Soviet Ukraine (2016), by American essayist Sophie Pinkham; and Ukraine: A Nation on the Borderland (the original, German edition, under the title Entscheidung in Kiew: Ukrainische Lektionen [Decision in Kyiv: Ukrainian Lessons], appeared in 2015), by the prominent German historian Karl Schlögel. All three authors show Ukraine and its people experiencing suffering and heroism-as a country and a society with a rich and complex history and promising future. Furthermore, the authors exhibit sharp powers of observation, wit, and critical thinking, and they rarely, if ever, resort to depicting the locals through caricature, stereotype, or mockery. 
Looking at these three works, Schlögel's book stands out in that it packages academic content in the form of a travelogue. It shows itself as a refined product of the evolving historical thought process of Germany's preeminent historian of twentieth-century Russia and the Soviet Union. The book, handsomely published, is a collection of essays written between 1987 and 2015 that stem from the author's extensive travels in Soviet and postSoviet Ukraine. Using a method that he calls "urban archaeology," he zeroes in on eight cities, "reading" and "decrypting" them as "textures and palimpsests ... in order to make their past speak" (14). This makes Schlögel not only an urban archeologist but also a medium of sorts-he channels the cities' speaking past through his own experience as a traveller. The book is part travelogue and part urban history of Ukraine. It features eight portraits of Ukraine's major cities-Kyiv, Odesa, Ialta, Kharkiv, Dnipro(petrovsk), Donetsk, Chernivtsi, and Lviv. Each city "speaks" about a particular past, highlighting a wider theme or historical period: the age of empires (Habsburg and Russian-multi-ethnic societies in which Jews had a particularly prominent role); the age of revolution(s); the interwar Soviet experiment (with its explosive mix of modernism, modernization, and terror); World War II (with the horrors of the Holocaust and German occupation); the Cold War military-industrial complex; the post-Soviet years filled with hope and despair; and finally, the Euromaidan and Vladimir Putin's aggression against Ukraine.

\section{UKRAINE THROUGH THE PRISM OF ITS CITIES}

Ukrainian cities are generally best "illuminated" by associating them, individually, with one or two specific epochs or themes. Kyiv, however, generates more attention than its urban peers. This city is first and foremost the "Vatican of Orthodoxy'" (86). But it is also an imperial multi-ethnic metropolis, the "third city' of the Russian Empire" (90), and a boom town of the Belle Époque. Its most famous visual symbol from the latter time is the so-called House with Chimaeras- "Art Nouveau cast in concrete" (93) - by architect Vladyslav Horodets'kyi (Władysław Horodecki), "Kiev’s Antonio Gaudí"' (93). But, of course, Schlögel, a distinguished student of Russia, does not forget that Kyiv was also the birthplace of writer Mikhail Bulgakov. It is through the literary eyes of Bulgakov and those of another Kyiv-born Russian writer, Il'ia Erenburg, that the author depicts life in revolutionary Kyiv (that portrait could have been fuller had the author included the Ukrainian perspective-for instance, Mykola Kulish's "revolutionary" drama Patetychna sonata [Sonata pathétique, 1929]). The most tragic pock on Kyiv's history is undoubtedly Babyn Iar and the extermination of almost the entire 
Jewish population of the city. More than thirty-three thousand people were cut down in just three days in this infamous ravine (the author relies heavily on the chilling eyewitness account of writer Anatolii Kuznetsov, who was twelve years old at the time). A glimmer of hope for Kyiv has come in the wake of the Euromaidan Revolution, owing to which the city "has shaken off the provincial drowsiness that was its lot in the imperial periphery" (115). Somewhat less compelling are the author's comments on Kyiv's being a potential centre of a free, "non-imperial Russian culture" (116; referring to the old hopes of Russian émigré philosopher Georgii Fedotov). But this Russian dream will likely not come to pass, at least not in the nearest future, owing to the ongoing Russian aggression, which has resorted to weaponizing even the famed Russian culture.

Odesa, more than any other city in present-day Ukraine, was (and to a large extent still is) universally celebrated as a wealthy cosmopolitan metropolis and a major Black Sea port-the proverbial "Southern Palmyra." When Schlögel visited Odesa in 2000, it was no longer the city of "prodigies and geniuses" (126), or even of "tricksters and thugs" (125), as typified in Isaak Babel"s short stories. It was a crumbling post-Soviet city trying to find its place in independent Ukraine. But while Foer imagines Odesa of the late 1990s as a ground zero for laissez-faire capitalism and a city of exaggerated cultural hybridity bordering on kitsch (best embodied by the character and actions of Alex, the protagonist's local fixer), Schlögel's depiction of Odesa from around the same time is much more elegiac and derives less energy from the typical Western clichés of a post-Communist hellhole. "Everyone is young and beautiful, like Greek deities or the runners on the beach in Santa Monica," the German traveller writes about the young Odesans enjoying promenades on warm summer nights in the city, which was recovering after years of Soviet stagnation and post-Soviet decay (134).

From Odesa the German academic-tourist journeyed further south, to the sun-drenched Crimea, which at that time was a young autonomous republic within Ukraine. Ialta, the peninsula's most famous spa town, is shown in the book as a symbol of Soviet mass tourism; earlier, it had served as a playground for the rich and famous from tsarist Russia. The town's transformation into an Eastern European Mallorca over the past two decades was abruptly halted by Russian invaders, who began busily turning the peninsula into a "restricted military area" (136).

Schlögel subsequently takes us to eastern Ukraine, starting with its largest metropolis, the city of Kharkiv. The city is introduced not only as the first capital of Soviet Ukraine but also as "a Capital of the Twentieth Century" (149) - a city of early Soviet modernity, Ukrainian modernism, and late Stalinist monumentalism (the so-called Stalinist Empire style). The most striking visual representation of this "Major European City Few Have Heard 
Of' (150) is the world-famous wonder of constructivist architecture the Derzhprom complex (1925-28). Kharkiv also stands for a new Ukraine that "awaits discovery" by Europe, as it is "unlike anything most Europeans have seen" (169). The author's sales pitch for Kharkiv is particularly ingenious: "A city like Kharkov is the right place for young adults who are tired of the Berlin club scene and want something different" (170)-that is, a city of Red modernism and of Serhii Zhadan, Kharkiv's most famous poet, writer, and civic activist.

Eastern Ukraine is represented in the book by two other cities. They are similar in many ways (both have been industrial powerhouses), but they also differ-for instance, regarding their reactions to the violent threat posed by Russia and its local sleeper cells in 2014. The city of Dnipro (previously Dnipropetrovsk; still earlier, Katerynoslav) has evolved from being the "City of Potemkin" to being the Soviet "Rocket City on the Dnieper." Today, it is seen as "Manhattan on the Dnieper"' (171). Thus, it was a city of imperial colonizers and cosmopolitan entrepreneurs that became a city of Soviet rocket scientists and military experts and, finally, ended up as a city of postSoviet oligarchs. But owing to these oligarchs, the city "has emerged as the centre of Ukrainian self-defence" in the months and years following Russia's annexation of the Crimea and its occupation of much of eastern Ukraine (172).

By contrast, the city of Donetsk became the epicentre of that occupation, following the so-called Russian Spring, Putin's (largely failed) plan to annex vast swaths of southern and eastern Ukraine. The city was established by Welshman John Hughes around 1869. By the end of that century, Iuzivka (Russian: Iuzovka) had grown into an industrial melting pot-a "future America"' (202) - but it had also become a hub of intense violence, which included worker unrest, Jewish pogroms, and police repression. From the time of its founding, Iuzivka had vacillated between having an unrestrained freedom typical of the steppe frontier and being subjected to extreme terror by the despotic state (as the American historian of the region Hiroaki Kuromiya has shown). Following long years of terror under Stalin and German occupiers, Iuzivka emerged as the city of Donetsk-a proud mining town in the postwar decades and a nest of soccer obsession. "[M]ining and football are central to the region's identity and its people's sense of pride," the author rightly notes (196). After the collapse of the Soviet Union, in the 1990s, Donetsk became a notorious gangland. Later, it was the power base of the pro-Russian Partiia rehioniv (Party of Regions) and the home turf of Ukraine's subsequently ousted president Viktor Ianukovych. Schlögel visited the city as it lay on the brink of disaster-in the spring of 2014, after a "small gang" of Russian servicemen and their local henchmen had already taken over the city's administrative buildings. He calls this takeover the 
"[k]idnapping" of the city and compares the new breakaway "republic" to the Gaza Strip and war-torn Somalia $(187,190)$. His prediction is sombre, and, as we know today, it has proven to be correct: Russia-controlled militants "turned the Donbass into a stomping ground for failed existences and imperialist adventurers who care nothing for the region's future and a testing area for Russian military experts trying out new forms of warfare" (219).

In contrast to the eastern part of Ukraine and cities like Donetsk, the Ukrainian West has long been considered the hotbed of modern Ukrainian nationalism. For Schlögel, however, this region is more interesting as material evidence of Ukraine's Habsburg past, when large parts of the country's western regions unquestionably belonged to Europe. The historian visited Chernivtsi, the former capital of the Austrian province of Bukovyna, in 1988, when the city was still barely accessible to a Western traveller. His essay on Chernivtsi is one of the best pieces in the book. Schlögel journeyed to the heart of an elusive, and by 1988 vanished, old Central Europe-to a city "where contemporary maps end," namely, one that is "marginalized, almost excluded, by cartography" (221-22). Chernivtsi was indeed hard to reach in those years, but Schlögel's sense of cartographic uncertainty is amplified by another feeling of deficiency - the loss of the city's multi-ethnic past, or of what he nostalgically calls the "miniature replica of the multiethnic empire, a 'Little Austria'” (230). This birthplace of the poets Paul Celan and Rose Ausländer, this bulwark of German culture in the east of Europe, and this "City upon a Hill" (220), in which Jews, Ukrainians, Romanians, Germans, and Poles had lived in relative harmony until at least 1918, was all but gone after the Holocaust and the arrival of the Soviets. Remarkably, Soviet modernity, which Schlögel sees as appropriate and openly celebrates in the cases of Kharkiv and Donetsk, seems in his mind totally out of place in Chernivtsi: "[T] he promises of a [Soviet] modernity" brought "central heating and private bathrooms with running hot water-and turned the world ugly and grey." The beautiful old facades "no longer glow from within" (245). And yet, amid all of the ugly and grey late Soviet urbanism, the traveller already saw a few signs of hope: the local Jewish community was feeling more confident, and literary relations with Germany (even if it was still East Berlin) were becoming stronger. In 2015, there were many more hopeful signs (such as the existence of the Meridian Czernowitz literary festival), but there were also challenges. One of the most difficult tasks has been developing appropriate mechanisms for preserving the city's "rich and complex cultural heritage" (221) while incorporating it into Ukrainian culture.

Lviv, the final destination described in the book, has encountered the same difficulty. Lviv is the unofficial capital of western Ukraine, but it prides itself on being the cultural capital of Ukraine as a whole. Historically, Lviv, according to Joseph Roth (translated), was a city of "'blurred boundaries"' 
(260). However, in recent times, importantly, Lviv has finally returned to being part of Europe-or as Schlögel puts it, the city "is back" (248). Habsburg Lviv was just like Habsburg Chernivtsi-a product of the empire, that is, of its "progressive paternalism" (257). Like Chernivtsi, Lviv lost its multi-ethnic population in the 1940s, at a time when "civic coexistence" (perhaps somewhat idealized by the author) was "detonated by policies of extermination" (263). When the author first travelled to Lviv in 1988, he thought that he was visiting "the forgotten slow-beating heart of Europe" (254). But already then, he was urging Europe to "outgrow the shadows of the Iron Curtain" and embrace cities like Lviv, that is, cities of "blurred boundaries"' (267).

\section{UKRAINE: PERSPECTIVE FOR THE FUTURE}

Schlögel's personal intellectual and ideological journey has been no less daring than his physical movements across time and space in Ukraine (take, for instance, his tiring railway trips in late Soviet times or his truly dangerous voyage to Donetsk in the wake of the city's takeover by Russia-controlled militants). As the historian himself admits, Ukraine was never on his professional radar, and it took the Euromaidan and the onslaught of Russian aggression in Ukraine to redirect his scholarly attention from Russia to this main victim of its armed aggression. This unexpected war (unforeseen, at least, in the eyes of Schlögel's fellow citizens in Germany) also amounted to an "invasion of reality" (269) and to the return of history "with a big bang" (272) after it had presumably ended around 1989 (a global event infamously announced by Francis Fukuyama). History may indeed have been "back," but Russia's annexation of the Crimea and its military intervention in eastern Ukraine also launched a war on historians like Schlögel-the past was replaced by the present, and Schlögel and his colleagues were deprived of the distance required to practise their craft. They (in fact, all of us) were forced to bear witness to violence and the violation of international law. As a result, Schlögel could no longer remain neutral: the events forced him to take a stand. He urges his readers, particularly those in Germany, to do the same by reconsidering the often uncritical apologetic attitude toward Russia, which is based not only on callous business interests but also on a misplaced guilt for the crimes committed during World War II against "'the Russians'” (35). Ukraine together with Belarus-countries that were completely overrun by the Nazi war machine-remain invisible in such a narrative. With a commendable intellectual candour, the author admits to having failed to recognize the signs of Russia's increasingly aggressive behaviour. Furthermore, the historian-turned-political commentator plainly states, with 
witty sarcasm, what many in the West, including those in his native Germany, have chosen to ignore for far too long:

The so-called Ukraine crisis is a Russian crisis first and foremost, brought on by a government that was never up to the task of a century: modernizing a nation. Occupying Crimea in a small operation executed with surgical precision turned out to be easier than finishing the Moscow-St Petersburg motorway. (38)

But there is more at stake than just the fate of Ukraine: "The attack on Ukraine is an attack not only on Ukraine," Schlögel bluntly writes. "At stake is Europe, [and] the West . . ." (76). By taking a stand against Russian aggression, Europeans would be simultaneously defending Europe against what the author views as Putin's "International," consisting of the Russian autocrat's European allies "from the far left to the far right" (9). The first task of intellectuals in defending both Ukraine and Europe is to recognize a few basic "distinctions" - "between the aggressor and the victim of his attack" and "between fact and fiction, between truth and lie" (77). Schlögel's book is a compelling attempt to tell the truth about Ukraine - that it is a pluralistic society with diverse historical narratives and legacies and that it is under attack by a fierce Russian disinformation campaign.

In light of the ravages of this information warfare, it is great news that Schlögel's important book has finally become accessible to an Englishspeaking audience. This is a fine translation by Gerrit Jackson, and it was authorized by the eminent historian Schlögel himself. Both the academic and non-academic reader will find the book compelling, enjoyable, and enlightening.

Schlögel, following in the 1769 footsteps of his fellow German intellectual and well-wisher of Ukraine Herder, travelling and writing, though, almost two hundred fifty years later, is hopeful about what lies in store for the country (it needs strong support from Europe, however, in order to become present). After Herder's time, Ukraine did not become “a new Greece." But it now has the rare chance of finding itself_-of realizing its unique present destiny and, thus, ceasing to be a country with a perpetually tantalizing but unattainable future. Ukraine faces numerous challenges, both external and internal, and more than ever, it needs friends abroad-that is, sympathetic but critical friends. The fragile and endangered Ukraine of today should consider itself lucky to have found such a friend in Schlögel. 


\section{Works Cited}

Foer, Jonathan Safran. Everything is Illuminated. Houghton Mifflin, 2002.

Fukuyama, Francis. The End of History and the Last Man. Free Press, 1992.

Horodets'kyi, Vladyslav, architect. House with Chimaeras. 1901-02, Kyiv. Building. Ignatieff, Michael. Blood and Belonging: Journeys into the New Nationalism. Farrar, Straus and Giroux,1995.

Kuromiya, Hiroaki. Freedom and Terror in the Donbas: A Ukrainian-Russian Borderland, 1870s-1990s. Cambridge UP, 2002. Cambridge Russian, Soviet and Post-Soviet Studies 104, edited by Stephen White et al.

Pinkham, Sophie. Black Square: Adventures in Post-Soviet Ukraine. W. W. Norton, 2016.

Pritsak, Omeljan. "V. Lypyns'kyj's Place in Ukrainian Intellectual History." Harvard Ukrainian Studies, vol. 9, nos. 3-4, December 1985, pp. 245-62.

Schlögel, Karl. Entscheidung in Kiew: Ukrainische Lektionen [Decision in Kyiv: Ukrainian Lessons]. Carl Hanser Verlag, 2015.

Serafimov, Sergei, et al., architects. Derzhprom. 1925-28, Kharkiv. Building. Szczerek, Ziemowit. Tatuaż z tryzubem. Wydawnictwo Czarne, 2015. Sulina. 